\title{
パラレルメカニズム形機械のフレームの変形補正に関する研究* (アッベの原理に基づく補正装置の改良)
}

大岩 孝彰*1, 寺澤 祐哉 ${ }^{* 2}$

\section{Compensation System for Machine Frame Deformations of Parallel Kinematic Machine (Abbe's Principle-Based Improvement of Compensation Device)}

\author{
Takaaki OIWA $^{* 1}$ and Yuuya TERASAWA \\ ${ }^{* 1}$ Shizuoka Univ. Dept. of Mechanical Engineering \\ Johoku 3-5-1, Naka-ku, Hamamatsu, 432-8561 Japan
}

This study deals with a compensation method for elastic and thermal deformations of the machine frame supporting the mechanism of the parallel kinematic machine (PKM). These deformations caused by external forces and heat in operation produce considerable relative motion errors between the tool and the workpiece of the machine. In the proposed method, three displacement sensors with Super-Invar rods measure distance variations among three spherical joints connecting the mechanism. Thus, the base platform's dimensions of the PKM are corrected by these measured distance variations. Moreover, six other displacement sensors with rods measure the distance variations between the machine's surface plate and the three joints. Therefore, the forward kinematics of the hexapod mechanism calculates displacement and attitude variations of the base platform in operation from these measured displacements. Consequently, coordinates of the PKM's end effector can be compensated by the dimensions, the displacement, and the attitude of the base platform in operation. In this paper, the above system was improved for an experimental coordinate measuring machine using a three-degree of freedom parallel manipulator. Mainly, each sensor with rod was rearranged based on the Abbe's principle to minimize the offsets between the sensor axis and the joint. Coordinate measurements using a master ball mounted on the surface plate showed that this device decreased the influences of temperature fluctuation and external force on machine accuracy.

Key Words : Parallel Kinematic Machine, Error Compensation, Frame Deformation, Thermal Expansion, Machine Tool, Coordinate Measuring Machine

\section{1. 緒言}

工作機械や座標測定機の加工・測定精度向上のためには，ツールと工作物の相対位置・姿勢精度が安定して得 られることが重要である.このためにはツールと工作物間の相対運動を受け持つメカニズム部分の精度向上だけ でなく，それを保持しているべース・コラムなどの静的な構造物つまり機械のフレーム部が，静・動的かつ熱的 にも安定していなければならない．しかし現実の機械では，基礎から伝わる外乱，機構の運動に伴う重心移動お よび切削抵抗などの加工負荷などさまざまな要因により，機械全体つまりメカニズムとフレームは変形する.さ らに室温変動や加工時に発生する熱などは機械全体の熱変形を引き起こす. 従来, 力学的変形を抑えるために機 械構造物の高剛性化が行われてきたが, 部材自体の質量増による変形や運動特性の悪化が生ずる. さらに熱変形 については，熱変位解析および機械に設置した温度センサや室温センサなどを用いて熱変形を予測・補正してき たが(1)ー(5), これらの有限個の温度センサでは構造物のごく一部の局所的な温度しか測れない. 特に複数台の直動 案内を直列的に接続した直交座標形機械に多く見られるはり構造では，複雑な変形が生じや寸く機械全体の変形

* 原稿受付 2013 年 7 月 2 日

*1 正員, 静岡大学大学院工学研究科（广432-8561 静岡県浜松市中区城北 3-5-1）

*2 静岡大学大学院 工学研究科

E-mail: tmtooiw@ipc.shizuoka.ac.jp 


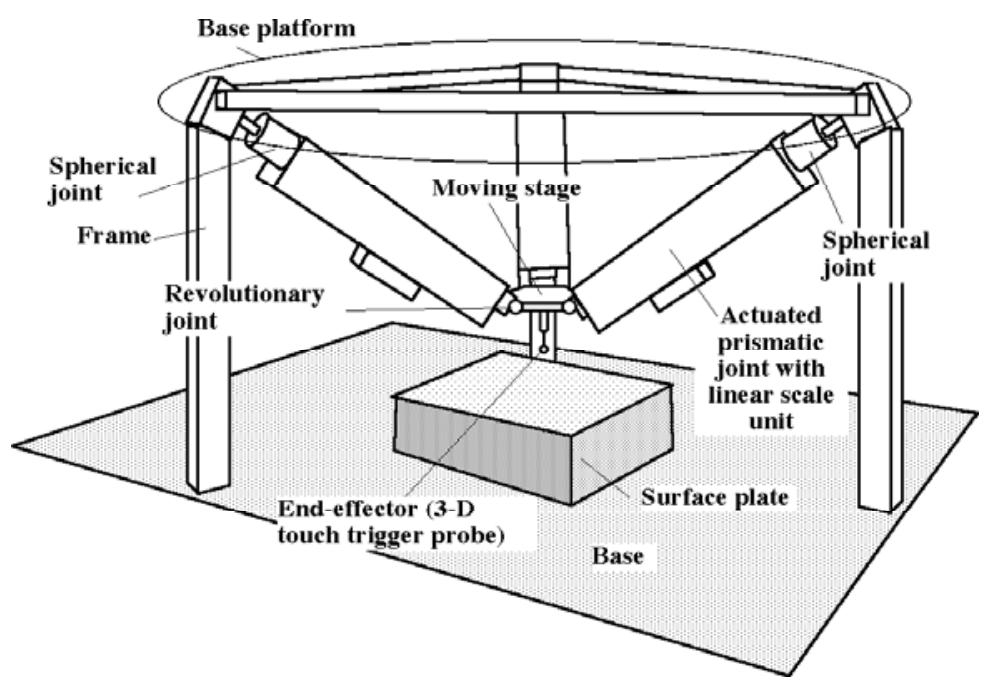

Fig. 1 Tripod-type coordinate measuring machine using three-degree-of-freedom parallel manipulator ${ }^{(5)}$

を高精度に補正することは困難となっていた。

一方, パラレルメカニズムはエンドエフェクタに対してアクチュエータを並列に配した空間リンク機構である. 近年，工作機械や座標測定機(6)などへの応用が進められているが，このようなパラレルメカニズム形機械におい てもさまざまな誤差が発生するため, 系統的な運動誤差を減ずるための機構パラメータの校正などの研究が各所 で行われている(7)-(9)．しかし，室温変動や外力などによる突発的な外乱に起因する再現性のない誤差に対しては 効果が期待できない. 一般的なパラレルメカニズムは図 1 に示すような機械フレームにメカニズムが吊り下げら

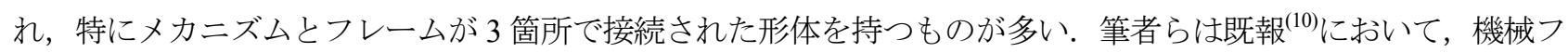
レームの変形はこれら 3 箇所の空間内の座標変化によって表されることに着目し，このような形体を持つ空間 3 自由度パラレルメカニズムのジョイントとリンクおよびフレームの弾性変形や室温変動に伴う熱的変形をインプ ロセスで計測し補正するシステムについて報告し，室温変動や外力に対する補正効果があることを示した。しか し, フレームの変形を計測する 9 台の変位計のアッベ誤差や, 3.2 節で詳述する計測ループ内の機械要素の熱変形 および摩擦などに起因し, 特に $Z$ 方向の補正精度が低下するという問題があった. そこで本報では, フレーム変 形測定装置に用いている 6 自由度パラレルメカニズムの誤差解析を行い，各基準点間の距離の計測誤差が補正精 度に及ぼす影響について調査した，次に上記のセンサの配置変更によるアッベオフセットの低減や構成部品の材 質の見直し,および摩擦の排除を行い, フレームの変形補正システムの性能向上を行った結果について報告する.

\section{2. 原理}

\section{$2 \cdot 1$ 概要}

緒言に述べたように，さまざまな内・外乱により機械の構造物やフレームは力学的・熱的変形を生ずる.もち ろん機械を設置するべースや基礎も例外ではない，そこで本研究では工作物の搭載される定盤を絶対的な基準と する. この定盤から見たパラレルメカニズムのベースプラットフォームの位置, 姿勢および大きさをインプロセ スで計測すれば， ベースプラットフォームを支えるフレームの材質や構造さらにフレームを支持する基礎の変形 などに関係なく,パラレルメカニズムのフレームの力学的および熱的な変形補償が行えると考えられる.さらに, 図 1 に示寸 3 自由度パラレルメカニズムのベースプラットフォーム自体は, 120 이日月隔で配置された 3 個の球面ジ ヨイントから構成されている，そこで，図 2 に示寸ように 6 個の基準点 $m_{i}(i=1, \cdots, 6)$ を定盤面に，3個の基準点 $b_{j}(j=1, \cdots, 3)$ をべースプラットフォーム上の 3 個の球面ジョイントの中心に設置する．このようにすれば，定盤 上に設置された座標系から見た基準点 $b_{j}$ を結ぶ三角形の位置, 姿勢および大きさは, 図中の 3 本の破線で示した ベースプラットフォーム上の基準点間の距離 $t_{j}$ および 6 本の一点鎖線で示した同基準点と定盤上の 6 個の基隻点 間の距離 $u_{i}$ の合計 9 個の距離によって一意に決定される. よって, ベースプラットフォームの位置・姿勢および 大きさの変動は以上の 9 つの距離の微小な変化を 9 台の変位センサで計測することにより求めることができる. 


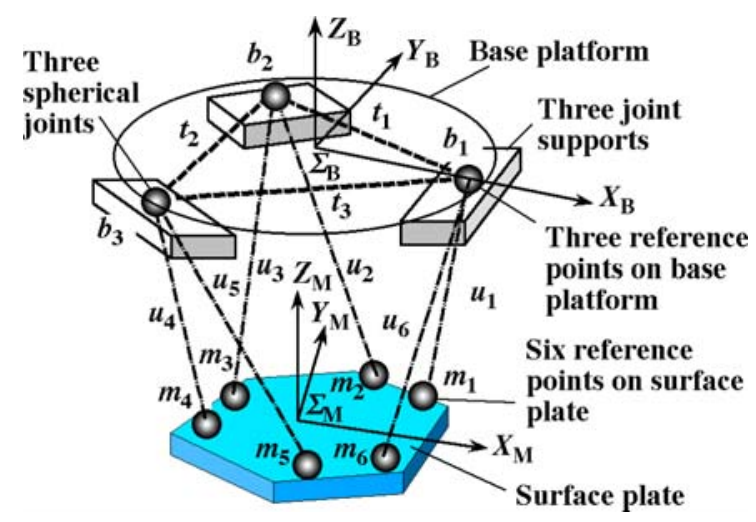

Fig. 2 Nine reference ponits on surface plate and base platform

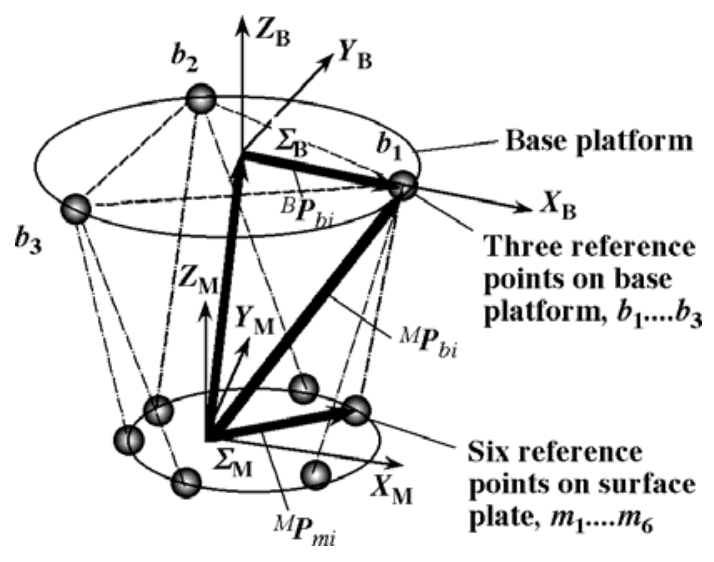

Fig. 3 Two coordinate systems including of reference points on base platform and surface plate

\section{$2 \cdot 2$ ベースプラットフォームの位置・姿勢の計算}

まず, 図 3 に示すようにベースプラットフォーム上の基準点間の三つの距離 $t_{j}$ からベースプラットフォーム座 標系 $\Sigma_{\mathrm{B}}$ を設定し，そこからみた基準点 $b_{j}$ の位置ベクトル ${ }^{\mathrm{B}} \boldsymbol{P}_{b j}(j=1, \cdots, 3)$ で表す．ここで肩字 B は座標系 $\Sigma_{\mathrm{B}}$ で表 されたベクトルであることを示寸. 本研究では座標系 $\Sigma_{\mathrm{B}}$ の原点を 3 個の基準点 $b_{j}$ の重心の位置とし,$X Y$ 平面が それら 3 点を含み, $X$ 軸が点 $b_{1}$ を通るように設定した. 同様に定盤上に設置した基準点からなる定盤座標系を $\Sigma_{\mathrm{M}}$ とし，この定盤座標系 $\Sigma_{\mathrm{M}}$ から見たベースプラットフォーム座標系 $\Sigma_{\mathrm{B}}$ の位置を表す位置ベクトルと姿勢を表す回 転変換行列をそれぞれ ${ }^{\mathrm{M}} \boldsymbol{P}_{\mathrm{B}}$ および ${ }^{\mathrm{M}} R_{\mathrm{B}}$ とすると, 定盤座標系 $\Sigma_{\mathrm{M}}$ から見たベースプラットフォーム上の基準点 $b_{j}$ の位置を表すべクトル ${ }^{\mathrm{M}} \boldsymbol{P}_{b j}(j=1,2,3)$ は以下の式で表される.

$$
{ }^{M} \boldsymbol{P}_{b i}={ }^{M} \boldsymbol{P}_{B}+{ }^{M} R_{B}{ }^{B} \boldsymbol{P}_{b i}
$$

また, ベースプラットフォーム上の基準点 $b_{j}$ から定盤上の基準点 $m_{i}$ までの距離 $u_{i}$ は, 定盤座標系 $\Sigma_{\mathrm{M}}$ から見た 定盤上の 6 個の基準点 $m_{i}(i=1, \cdots, 6)$ の位置ベクトルを ${ }^{\mathrm{M}} \boldsymbol{P}_{m i} \quad(i=1, \cdots, 6)$ とすれば,

$$
\begin{aligned}
& u_{1}=\left|{ }^{M} \boldsymbol{P}_{b_{1}}-{ }^{M} \boldsymbol{P}_{m 1}\right|, \quad u_{2}=\left|{ }^{M} \boldsymbol{P}_{b_{2}}-{ }^{M} \boldsymbol{P}_{m 2}\right|, \quad u_{3}=\left|{ }^{M} \boldsymbol{P}_{b_{2}}-{ }^{M} \boldsymbol{P}_{m 3}\right| \text {, } \\
& u_{4}=\left|{ }^{M} \boldsymbol{P}_{b_{3}}-{ }^{M} \boldsymbol{P}_{m 4}\right|, \quad u_{5}=\left|{ }^{M} \boldsymbol{P}_{b_{3}}-{ }^{M} \boldsymbol{P}_{m 5}\right|, u_{6}=\left|{ }^{M} \boldsymbol{P}_{b_{1}}-{ }^{M} \boldsymbol{P}_{m 6}\right| \text {. }
\end{aligned}
$$

である. 3.1 節で述べるように定盤は低膨張鋳鉄で製作し熱変形がないものとするため, ${ }^{\mathrm{M}} \boldsymbol{P}_{m i}$ は定数となる. こ れらの 6 つの距離 $u_{i}$ を用いて定盤座標系 $\Sigma_{\mathrm{M}}$ から見たベースプラットフォーム座標系 $\Sigma_{\mathrm{B}}$ の位置 ${ }^{\mathrm{M}} \boldsymbol{P}_{\mathrm{B}}$ と姿勢 ${ }^{\mathrm{M}} R_{\mathrm{B}}$ を 求める, つまり 6 個の未知数を求めるためには以上の非線形連立方程式を数值解法で解く必要があるが，これは 代表的な伸縮型 6 自由度パラレルメカニズム（ヘキサポッド）の順運動学となる.

\section{$2 \cdot 3$ エンドェフェクタの位置·姿勢の補正}

本節では前節で得られたベースプラットフォームの位置 ${ }^{\mathrm{M}} \boldsymbol{P}_{\mathrm{B}}$ と姿勢 ${ }^{\mathrm{M}} R_{\mathrm{B}}$ からパラレルメカニズムのエンドエフ エクタの位置と姿勢を補正する手順を説明する.

(1) 一般的に $\mathrm{NC}$ 機械等を稼働する直前には原点復帰を行うが，このときの基準点間の距離 $t_{0 j}(j=1,2,3)$ お よび $u_{0 i}(i=1, \cdots, 6)$ を初期長さとして図 4 のように基準ベースプラットフォーム座標系 $\Sigma_{\mathrm{B} 0}$ を設定する. 定盤座標系 $\Sigma_{\mathrm{M}}$ からみた座標系 $\Sigma_{\mathrm{B} 0}$ の位置と姿勢は ${ }^{\mathrm{M}} \boldsymbol{P}_{\mathrm{B} 0}$ および ${ }^{\mathrm{M}} R_{\mathrm{B} 0}$ で表される.

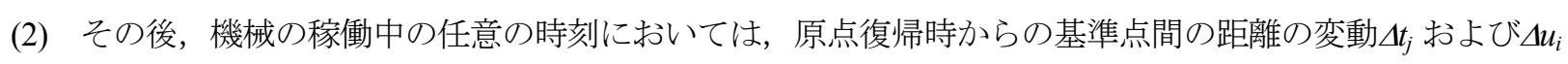
を9台の微小変位計にて測定する. 寸なわち, 


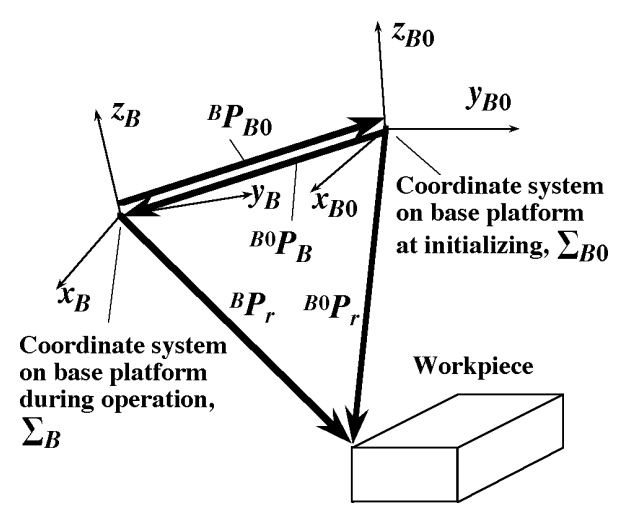

Fig. 4 Two coordinate systems at initializing and during operating

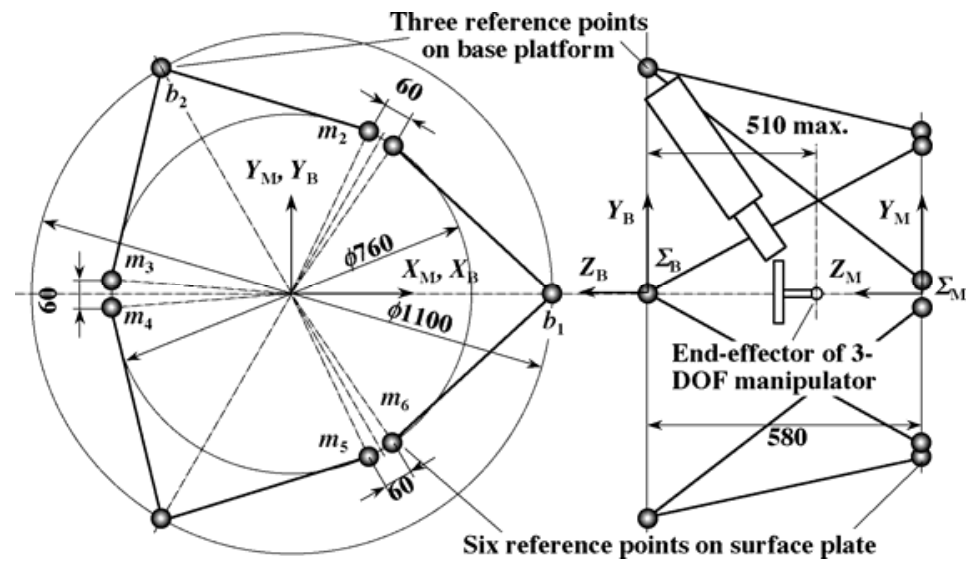

Fig. 5 Link configuration of 6-dof parallel mechanism

$$
\begin{array}{ll}
t_{i}=t_{0 i}+\Delta t_{i} & (i=1, \cdots, 3) \\
u_{i}=u_{0 i}+\Delta u_{i} & (i=1, \cdots, 6)
\end{array}
$$

(3) 以上の值と 6 自由度へキサポッドの順運動学を用いて定盤座標系 $\Sigma_{\mathrm{M}}$ からみた任意の時刻におけるべー スプラットフォーム座標系 $\Sigma_{\mathrm{B}}$ の位置 ${ }^{\mathrm{M}} \boldsymbol{P}_{\mathrm{B}}$ および姿勢 ${ }^{\mathrm{M}} R_{\mathrm{B}}$ を求める.

(4) 工作機械の場合, 変形したフレーム上のベースプラットフォーム座標系での目標值ベクトルを求めるた めに，基準ベースプラットフォーム座標系 $\Sigma_{\mathrm{B} 0}$ から見た目標值 ${ }^{\mathrm{B} 0} \boldsymbol{P}_{r}$ を，任意の時刻におけるベースプラッ トフォーム座標系での座標值 ${ }^{\mathrm{B}} \boldsymbol{P}_{r}$ に次のベクトル計算により変換する.

$$
{ }^{B} \boldsymbol{P}_{r}={ }^{B} \boldsymbol{P}_{B 0}+{ }^{B} R_{B 0}{ }^{B 0} \boldsymbol{P}_{r}
$$

ここで, ${ }^{\mathrm{B}} \boldsymbol{P}_{\mathrm{B} 0}$ および ${ }^{\mathrm{B}} R_{\mathrm{B} 0}$ は任意の時刻におけるベースプラットフォーム座標系 $\Sigma_{\mathrm{B}}$ から見た原点復帰時の 基準ベースプラットフォーム座標系 $\Sigma_{\mathrm{B} 0}$ の位置ベクトルおよび回転変換行列である. さらにエンドエフェ クタの姿勢は回転変換行列 ${ }^{\mathrm{B}} R_{\mathrm{B} 0}$ により目標姿勢を修正する. 次に，その目標值からその移動に必要なア クチュエータの移動量を逆運動学にて計算し，アクチュエータを駆動する.

(5) 座標測定機などでは, 変形したフレームで測定した座標值 ${ }^{\mathrm{B}} \boldsymbol{P}_{r}$ を常に原点復帰時の基準座標系 $\Sigma_{\mathrm{B} 0}$ で表す 必要がある. まず順運動学でベースプラットフォーム座標系 $\Sigma_{\mathrm{B}}$ から見た稼働中の測定值 ${ }^{\mathrm{B}} \boldsymbol{P}_{r}$ を算出し, そ の後, 原点復帰時の基準ベースプラットフォーム座標系 $\Sigma_{\mathrm{B} 0}$ での座標值 ${ }^{\mathrm{B} 0} \boldsymbol{P}_{r}$ に次のベクトル計算により変 換する.

$$
{ }^{B 0} \boldsymbol{P}_{r}={ }^{B 0} \boldsymbol{P}_{B}+{ }^{B 0} R_{B}{ }^{B} \boldsymbol{P}_{r}
$$

\section{$2 \cdot 4$ 装置の誤差解析}

本節では 2.1 節で述べたベースプラットフォームの位置 ${ }^{\mathrm{M}} \boldsymbol{P}_{\mathrm{B}}$ および姿勢 ${ }^{\mathrm{M}} R_{\mathrm{B}}$ の計測精度と各部材毎の許容誤差 (熱膨張や変形) の関係について調べるために誤差解析を行う。誤差要因は種々同時に発生し重祇合わされて誤 差伝搬するため, 補正装置全体の精度を正確に見積もることは困難であるが，本報では温度変動が $1^{\circ} \mathrm{C} の$ 時の補 正精度を $1 \mu \mathrm{m}$ 以内とするための各許容值を求めるものとする.ここでは 6 自由度へキサポッド機構の微小運動学 を用いた特異值解析を行い，各基準点の位置誤差や距離測定誤差が及ぼす影響について調査する。まず，基準点 間の 6 組の距離 $\boldsymbol{u}_{i}(i=1 \ldots 6)$ の変動 $\Delta \boldsymbol{u}_{i}=\left(\Delta u_{1}, \ldots, \Delta u_{6}\right)^{\mathrm{T}}$ とベースプラットフォームの 6 自由度の微小な運動誤差 $\Delta \mathrm{x}=(\Delta \mathrm{x}, \Delta y, \Delta z, \Delta \alpha, \Delta \beta, \Delta \gamma)^{\mathrm{T}}$ の関係は

$$
\Delta \boldsymbol{x}=J \Delta \boldsymbol{u}
$$

のように6×6 のヤコビ行列 $J$ を用いて線形的に表すことができる. これは変位計測誤差 $\Delta u$ とベースプラットフォ 一ムの位置 ${ }^{\mathrm{M}} \boldsymbol{P}_{\mathrm{B}}$ および姿勢 ${ }^{\mathrm{M}} R_{\mathrm{B}}$ の計測誤差の関係を示す. 次にこのヤコビ行列 $J$ の特異值分解を行い，6つの特 


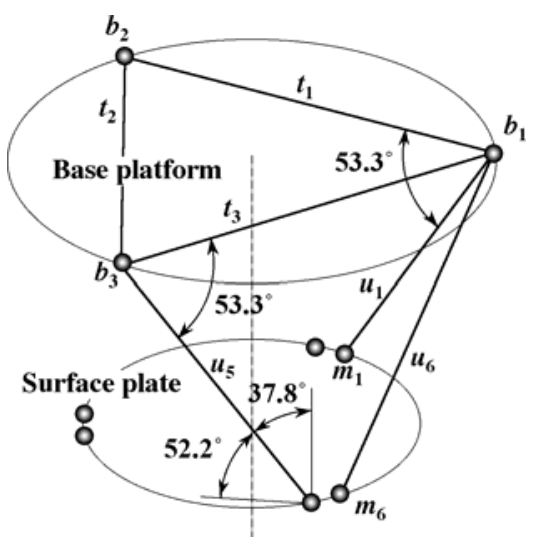

Talble 1 Tolerance in each direction to compensate end-effector's position with $1 \mu \mathrm{m}$ accuracy

\begin{tabular}{c|c} 
Direction of error & Tolerance $\boldsymbol{\mu} \mathbf{m}$ \\
\hline \hline$u_{i}$ & $\mathbf{0 . 4 5}$ \\
\hline$t_{i}$ & $\mathbf{0 . 7 6}$ \\
\hline $\begin{array}{l}\text { Horizontal to base } \\
\text { platform or surface plate }\end{array}$ & $\mathbf{0 . 7 4}$ \\
\hline $\begin{array}{l}\text { Vertical to base platform } \\
\text { or surface plate }\end{array}$ & $\mathbf{0 . 5 7}$ \\
\hline
\end{tabular}

Fig. 6 Included angle between measuring direction and base platform and surface plate

異值 $\lambda_{i}(i=1 \ldots 6)$ を求めると, その性質がより明らかになる.つまり距離 $\boldsymbol{u}$ の変動 $\Delta \boldsymbol{u}$ が $\lambda_{i}$ 倍されてベースプラッ トフォームの運動誤差 $\Delta x$ に現れる. そこで図 5 に示寸本論文で用いた 6 自由度へキサポッドの運動学のヤコビ行 列 $J$ を特異值分解したところ, 並進方向 (位置) では 1.38 (単位: 無次元数) および回転方向 (姿勢) では $1.95 \mathrm{rad} / \mathrm{m}$ という最大特異值を得た。これは変位計測誤差 $\Delta \boldsymbol{u}$ が最大で 1.38 倍されて位置 ${ }^{\mathrm{M}} \boldsymbol{P}_{\mathrm{B}}$ の計測誤差となることを示し ている. また姿勢 ${ }^{\mathrm{M}} R_{\mathrm{B}}$ の計測誤差は，例えば変位計測誤差 $\Delta \boldsymbol{u}$ が $1 \mu \mathrm{m}$ の場合，最大で $1.95 \mu \mathrm{rad}$ となる可能性があ ることを示している．以上の誤差 $\Delta \boldsymbol{u}$ は定盤上の基準点 $m_{i}$ およびベースプラットフォーム上の基準点 $b_{j}$ の $\boldsymbol{u}$ 方向 の位置誤差と等価であり，この $\boldsymbol{u}$ 方向の誤差が位置姿勢計測精度に最も強く影響し，uに直角な方向の誤差の影 響は僅少となる ${ }^{(11)}$. 例えば, ベースプラットフォーム上の基準点 $b_{j}$ のある方向の位置誤差の大きさが $\left|\Delta b_{j}\right|$ である とき，位置 ${ }^{\mathrm{M}} \boldsymbol{P}_{\mathrm{B}}$ の計測誤差は最大で $1.38 \times\left|\Delta b_{j}\right| \cos \theta$ となる（ここで $\theta$ は誤差の方向と $\boldsymbol{u}$ とのな寸角）。上式は誤差 が $\boldsymbol{u}$ 方向で最大, $\boldsymbol{u}$ に直角な方向では 0 となることを示している. 用いたへキサポッド機構についての $\boldsymbol{u}$ 方向, $\boldsymbol{t}$ 方向, ベースプラットフォームおよび定盤との角度関係を図 6 に示す.

さらに本研究で扱うパラレルメカニズム形機械ではフレームに 3 自由度パラレルメカニズムが吊り下げられた 構造を持つため, ベースプラットフォームの位置 ${ }^{\mathrm{M}} \boldsymbol{P}_{\mathrm{B}}$ および姿勢 ${ }^{\mathrm{M}} R_{\mathrm{B}}$ の計測誤差は機械のエンドエフェクタの補 正精度に影響を及ぼす。ここで位置 ${ }^{\mathrm{M}} \boldsymbol{P}_{\mathrm{B}}$ の計測誤差は直接エンドエフェクタ先端の位置誤差となり, 姿勢 ${ }^{\mathrm{M}} R_{\mathrm{B}}$ の 計測誤差はベースプラットフォームからエンドエフェクタまでの距離により拡大されて位置誤差となって現れる。 本研究での 3 自由度パラレルマニピュレータではこの距離は最大 $510 \mathrm{~mm}$ (ベースプラットフォームから測定定盤 までの距離，図 5) であるが，この位置でのエンドエフェクタの並進方向の最大特異值を求めたところ 2.21 であ った (回転方向は $1.95 \mathrm{rad} / \mathrm{m}$ で変わらず)。これは装置の距離 $\boldsymbol{u}$ 方向の $1 \mu \mathrm{m}$ の誤差は最大で $2.21 \mu \mathrm{m}$ のエンドエフ エクタの補正誤差を引き起こす可能性があることを示す. 以上からエンドエフェクタの位置決め誤差の補正を $1 \mu \mathrm{m}$ 以内の精度で行うためには装置の $\boldsymbol{u}$ 方向の誤差を $1 / 2.21 \mu \mathrm{m}=0.45 \mu \mathrm{m}$ 以内とすることが必要である.

ベースプラットフォーム上の基準点 $b_{j}$ 間の距離 $\boldsymbol{t}$ の方向の誤差 $\Delta \boldsymbol{t}$ の影響は, $\boldsymbol{t}$ 方向と $\boldsymbol{u}$ 方向の角度が最も小さ い場合で $53.3^{\circ}$ である（図 6）ので，前出の式より $2.21 \times\left|\Delta t_{i}\right| \cos \left(53.3^{\circ}\right)=1.32 \mu \mathrm{m}$ となる．また，定盤上の基準点 $m_{i}$ の半径方向の位置誤差の影響は，この半径方向と $\boldsymbol{u}$ 方向の角度が $84.7^{\circ}$ でありほぼ直交しているため,

$2.21 \times \cos \left(84.7^{\circ}\right)=0.20 \mu \mathrm{m}$ となり影響は小さい. また $\boldsymbol{u}$ 方向とベースプラットフォームおよび定盤面とのなす角は $52.2^{\circ}$ でありベースプラットフォームおよび定盤の $1 \mu \mathrm{m}$ の水平方向 $(x$ および $y$ 方向 $)$ の変形は最大で $2.21 \cos \left(52.2^{\circ}\right)$ $=1.35 \mu \mathrm{m}$ の補正誤差を生ずる可能性がある. また垂直方向 $(z$ 方向 $)$ は $2.21 \cos \left(90^{\circ}-52.2^{\circ}\right)=1.75 \mu \mathrm{m}$ となる. 以上の エンドエフェクタの補正を $1 \mu \mathrm{m}$ の精度で行うための許容值と誤差の方向の関係を表 1 にまとめた.

\section{3. 実験装置の改良}

\section{$3 \cdot 1$ 概要}

図 7 は既報で報告した空間 3 自由度を持つ 3-SPR 形パラレルマニピュレータを用いた三次元座標測定機の外観 を示している.この写真の補正システムは， 3.2 節から 3.5 節に述べられている改良を施す前のものである.この 


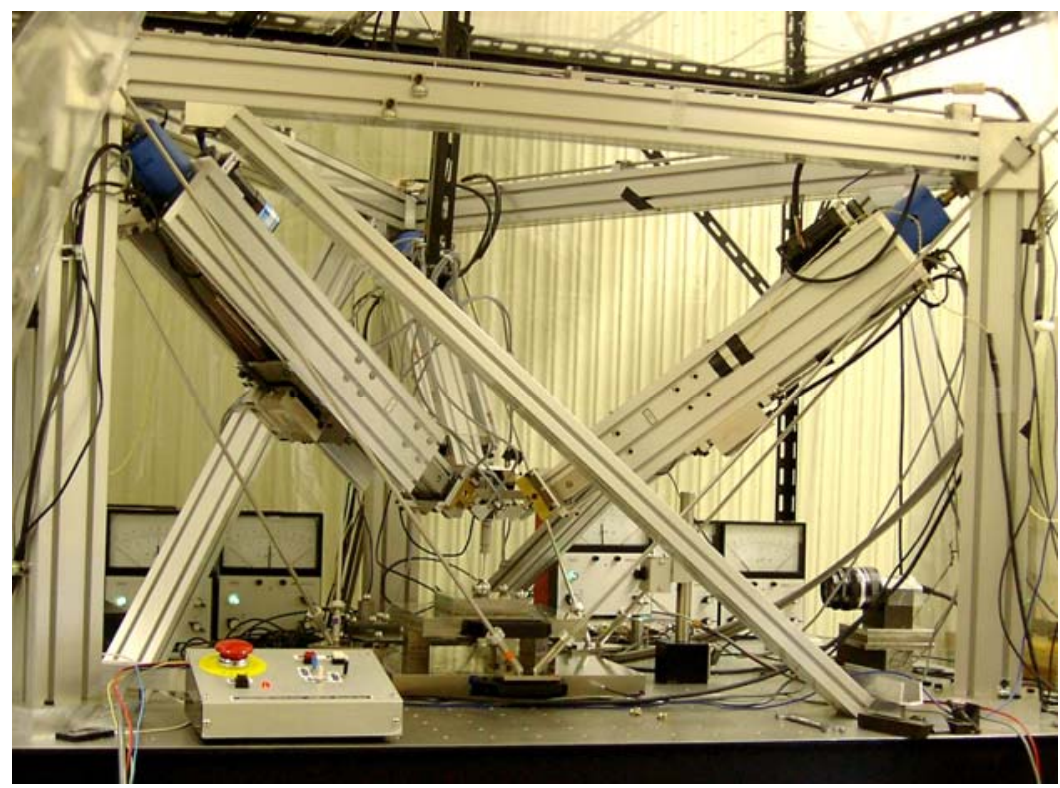

Fig. 7 Experimental coordinate measuring machine based on 3-SPR parallel manipulator with compensation system for machine frame deformations

パラレルメカニズム形機械のフレームに組み込んだ基準点間の距離 $t_{j}$ および $u_{i}$ の変化を測定する装置の一部分を 図 8 に示す. 本システムでは定盤を基準としてベースプラットフォームの位置・姿勢と大きさを計測するため, 定盤は低膨張鋳鉄（日本鋳造 LEX-SF1，線膨張係数 : 約 $0.8 \mathrm{ppm} / \mathrm{K}$ ）にて製作して 2.2 節で述べた 6 個の基準点 $m_{i}$ の相対位置の熱的変動を最小に保つようにした．定盤の大きさ（6つの基準点を通る円の直径）は約 $760 \mathrm{~mm}$ で あるので，定盤の熱膨張はこの值に線膨張係数と温度変化を乗じた值となる. 2.4 節の誤差解析より，定盤の水平 方向の変形の許容值は $0.74 \mu \mathrm{m}$ であるため, 定盤温度変動が $1^{\circ} \mathrm{C}$ 場合に熱膨張をこの值以下とするのに必要な 材料の線膨張係数は $0.74 \mu \mathrm{m} / \mathrm{K} / 0.76 \mathrm{~m}=0.97 \mathrm{ppm} / \mathrm{K}$ 以下となり，低膨張鋳鉄はこれを満たしている.また垂直方向 の寸法は小さいため熱膨張は僅少である.

この定盤上の 6 点からフレーム上のジョイントサポート 3 ケ所までの距離 $u_{i}$ の変動 $\Delta u_{i}$ を 6 本のスーパーイン バー製ロッド (径 $6 \mathrm{~mm}$, 線膨張係数 : 約 $0.5 \mathrm{ppm} / \mathrm{K}$ ) と 6 台の電気マイクロメータ（Mahr 社ミリトロン 1201IC, 測定誤差 $\leq 0.05 \mu \mathrm{m} ）$ により計測する. またジョイントサポート間の距離 $t_{j}$ の変動 $\Delta t_{j}$ も同様に 3 本のロッドと電気 マイクロメータ 3 台にて測定した. 機械稼働中にフレームが外力等により変形しても, ロッドには外力はかから ず，またロッドの熱膨張も微小であるため，ロッドの長さ変化は僅少である。したがって外力や室温変動の影響 を受けずに上記の 9 つの距離の変化を測定できる．距離 $u_{i}$ および $t_{j}$ は設計值で約 $720 \mathrm{~mm}$ および約 $950 \mathrm{~mm}$ である ので，ロッドやこれを支えるステーの熱膨張はこれらの值に線膨張係数と温度変化を乗じた值となる. 2.3 節の誤 差解析より， $u_{i}$ 方向と $t_{j}$ 方向の測定誤差許容值はそれぞれ $0.45 \mu \mathrm{m}$ および $0.76 \mu \mathrm{m}$ である. 部材温度変動が $1^{\circ}$ の場 合に必要な線膨張係数は $0.45 \mu \mathrm{m} / \mathrm{K} / 0.72 \mathrm{~m}=0.63 \mathrm{ppm} / \mathrm{K}$ および $0.76 \mu \mathrm{m} / \mathrm{K} / 0.95 \mathrm{~m}=0.80 \mathrm{ppm} / \mathrm{K}$ 以下となり，上述のスー パーインバー材はこれを満たしている.

同時にフレーム中央部と定盤付近の室温，フレームの 3 本の柱（アルミ A6063S）の中間部分および直動リン ク (アルミ $\mathrm{A} 6063 \mathrm{~S}$ ) の中央部の 3 ケ所合計 8 ケ所の温度をサーミスタ温度計 (テクノセブン $\mathrm{D} 642$, 分解能: $0.01^{\circ} \mathrm{C}$, 確度 : $\left.\pm 0.02^{\circ} \mathrm{C}\right)$ で計測した。 ただし，この温度計測データはフレームの熱変形補正のためには用いない.

\section{$3 \cdot 2$ 材質の変更}

高精度な補正のためには，定盤からジョイントサポートまでの距離の変動を室温変動などの影響を受けずに正 確に測定できることが重要であるが，これ以外に球面ジョイントからプローブまでのパラレルメカニズム自体の 熱変形を小さくする必要がある.つまり，機械全体の精度向上のためには図 8 に示した定盤・スーパーインバー 製ロッド・ジョイントサポート・球面ジョイント・連結連鎖・回転ジョイント・ムービングステージ・プローブ に至る計測ループ(12)のすべてが低膨張材料で製作されていることが望ましい. 計測ループとは変位センサと測定 


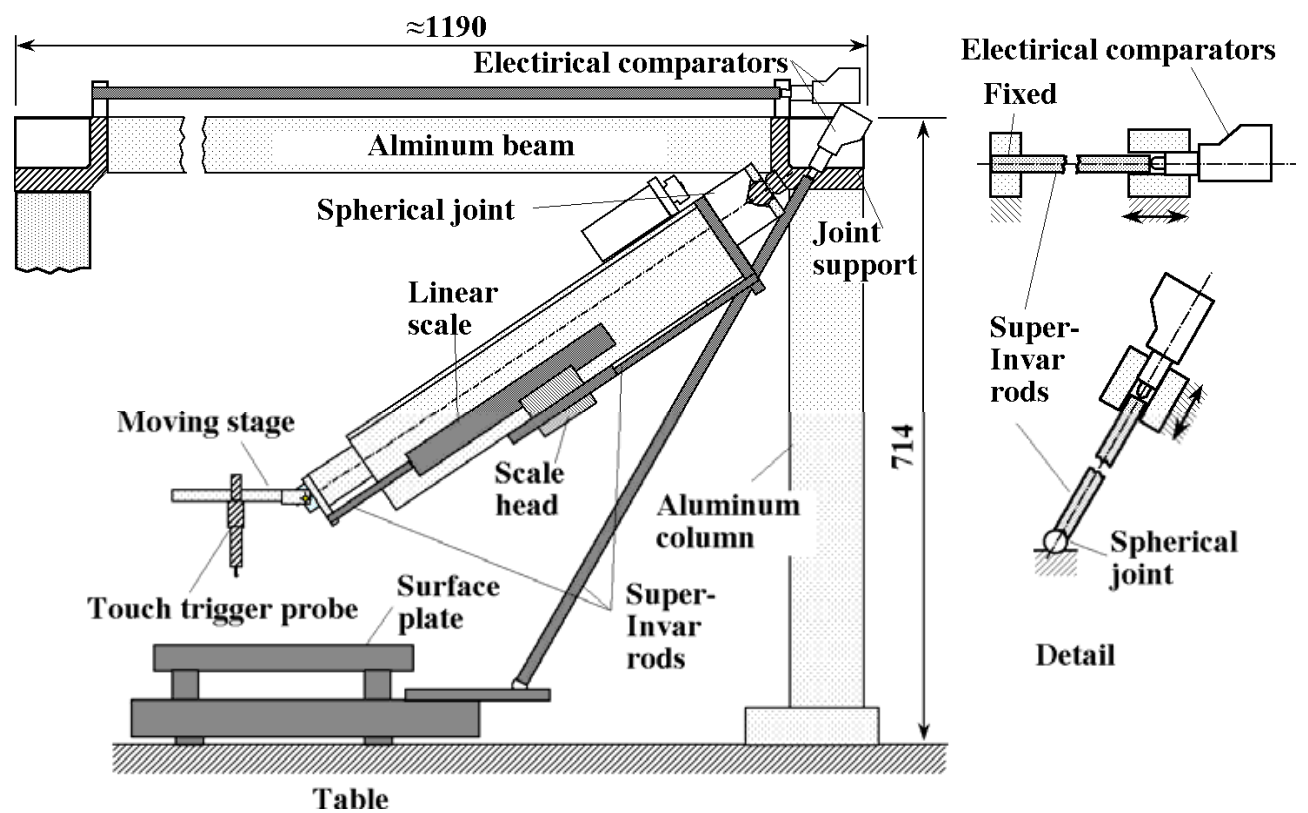

Fig. 8 Frame deformation measurement device using Super-Invar rods and electrical comparators

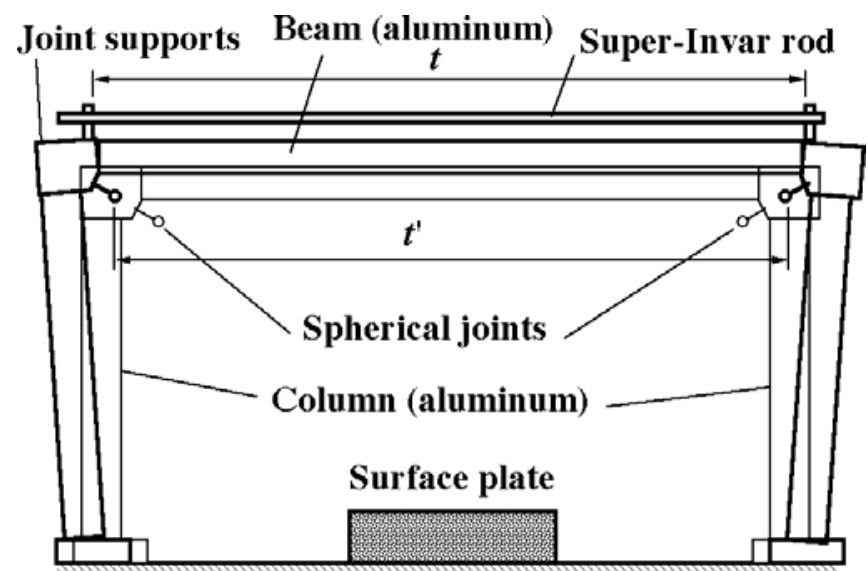

Table (stainless steel)

Fig. 9 Thermal deformation of machine frame

対象物を支持する部品すべてを通る閉曲線であり，このループに沿った部材の力学的および熱的変形を最小限に 留める必要がある．特に熱膨張は部材の長さに寸法に比例するため，ループに沿った寸法が大きい部材に低膨張 材を適用する必要がある．また，上記の計測ループのうち過大な力が作用しない部品には極低熱膨張材である低 膨張ガラスセラミクス（例えばゼロデュア®(ショット社, 線膨張係数 : $0.05 \pm 0.10 \mathrm{ppm} / \mathrm{K})$ やクリアセラム® $\mathrm{Z}$ (オ 八ラ， $0.0 \pm 0.1 \mathrm{ppm} / \mathrm{K}) ）$ なども利用可能であるが，加工性や入手容易性などを考慮して本報ではスーパーインバー および低膨張鋳鉄を採用した.

そこで, 前報 ${ }^{(10)}$ までアルミ(線膨張係数: 約 $\left.23 \mathrm{ppm} / \mathrm{K}\right)$ 製であったジョイントサポートとムービングステージ, さらに MC ナイロン（線膨張係数 : 約 $90 \mathrm{ppm} / \mathrm{K}$ ) 製であった球面ジョイント部をそれぞれ低膨張鋳鉄（榎本鋳工 所，ノビナイト CS-5, 線膨張係数 : $1.2 \mathrm{ppm} / \mathrm{K}$ ) で製作した. 図 8 に示寸連結連鎖部分には, リンクの弾性およ び熱的伸縮を内蔵のリニアスケールユニットで計測するシステム ${ }^{(10)}$ を組込んだ.

また, 外力や駆動力を支えるメカニズムや構造体を貫通するループはカループ(11) と呼ばれ, 測定ループが通過 する部位の力学的変形を最小限とするためには，二つのループを互いに分離させる必要がある. 本補正システム では, フレームの変形を計測するための計測系とメカニズムを支えるフレーム構造がほぼ分離していて, 外力や 駆動力の影響を受けにくい. 


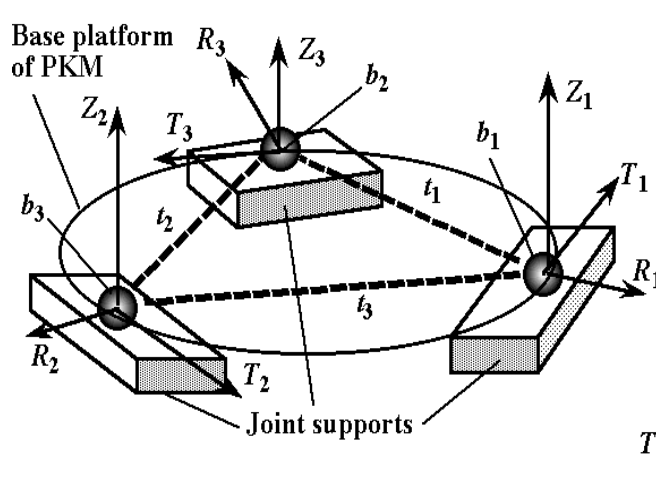

(a) Coordinate systems on joint supports

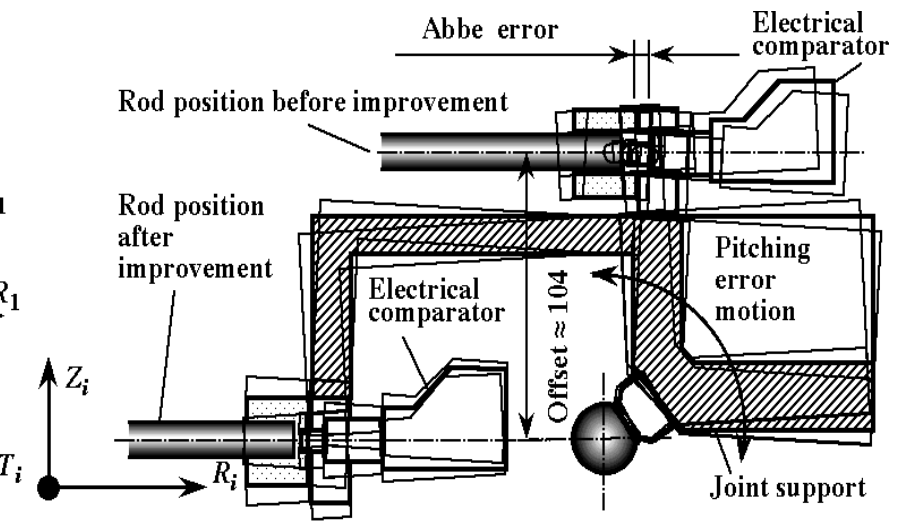

(b) Pitching error motion of joint support

Fig. 10 Abbe error caused by angular motion error in pitching direction

\section{$3 \cdot 3$ 上部ロッド位置の変更}

図 9 は温度上昇時のフレーム（梁および柱部分）の変形のようすを示している.フレーム上部の温度は下部よ りも通常 $1^{\circ} \mathrm{C}$ から $2^{\circ} \mathrm{C}$ 程度高く,アルミ製フレームの設置されている空気バネ式除振台のテーブルはステンレス鋼 製であるため, 図 10 に示すようなジョイントサポートの $T_{i}$ 軸回りの姿勢誤差（ピッチング誤差）が生ずる.こ の結果, 図中のジョイント間距離 $t$ の変化と測定される距離 $t^{\prime} の$ 変化の間には誤差が生ずる. この誤差は一般的な 一次元の長さ計測で発生するアッベ誤差 $(\Delta L=[$ オフセット $] \times \sin ($ 姿勢誤差 $) \approx[$ オフセット $] \times[$ 姿勢誤差 $])$ であ

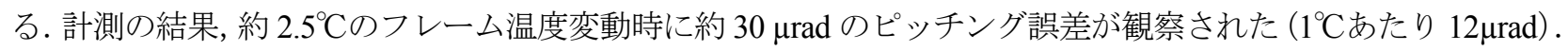
変位 $\Delta t_{j}$ を計測するロッドは球面ジョイント中心から約 $104 \mathrm{~mm}$ の高さにあるため, 上述の式からアッベ誤差は $1^{\circ} \mathrm{C}$ あたり約 $1.2 \mu \mathrm{m}$ となり, 表 1 の $\Delta t_{j}$ の許容值を超過する. そこで, ロッドを球面ジョイント中心高さまで下げ, オ フセットをできるだけ小さくすることにより姿勢誤差の影響を排除した.

さらに，図11 は上方より見たジョイントサポートの垂直軸（図 11 の $Z_{i}$ 軸）回りの姿勢誤差すなわちヨーイン

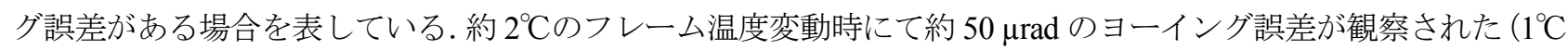
あたり約 $25 \mu \mathrm{rad}$ ）。ロッドと球面ジョイントとのオフセットは約 $50 \mathrm{~mm}$ 程度なので，ヨーイング誤差に起因する 変位 $\Delta t_{j}$ の測定誤差は $1^{\circ} \mathrm{C}$ あり約 $1.25 \mu \mathrm{m}$ となる. 同様に, 図に示寸ようにオフセットが小さくなるようにロッ ドおよび電気マイクロメータの配置を変更した．表 1 から変位 $\Delta t_{j}$ の計測誤差許容值は $0.76 \mu \mathrm{m}$ 以内であり，この ためのオフセットの最大許容值は, [オフセット許容值] $=0.76 \mu \mathrm{m} /$ [姿勢誤差]であるので, 姿勢誤差が $12 \mu \mathrm{rad} / \mathrm{K}$ および $25 \mu \mathrm{rad} / \mathrm{K}$ の場合はそれぞれ，0.76 $\mu \mathrm{m} / 12 \mu \mathrm{rad} / \mathrm{K}=63 \mathrm{~mm}$ および $0.76 \mu \mathrm{m} / 25 \mu \mathrm{rad} / \mathrm{K}=30 \mathrm{~mm}$ となる. 図 14 に 示す実験機では, オフセットは $\pm 10 \mathrm{~mm}$ 以内となるようにロッドおよび変位計を設置した。この場合，ピッチング 誤差 $12 \mu \mathrm{rad} / \mathrm{K}$ およびヨーイング誤差 $25 \mu \mathrm{rad} / \mathrm{K}$ の時のアッベ誤差は $10 \mathrm{~mm} \times 12.5 \mu \mathrm{rad} / \mathrm{K}=0.125 \mu \mathrm{m} / \mathrm{K}$ および $10 \mathrm{~mm} \times 25 \mu \mathrm{rad} / \mathrm{K}=0.25 \mu \mathrm{m} / \mathrm{K}$ 程度まで減少するものと推察される.

\section{$3 \cdot 4$ 下部ロッド位置の変更}

図 12 はフレーム中心部から見たジョイントサポートを示している. 図の左側は前報までの配置を表す. スーパ ーインバー製ロッド上部の電気マイクロメータはジョイントサポート両側部に配設されていたため, 定盤上の基 準点から球面ジョイントまでの直線に対するオフセットが約 $80 \mathrm{~mm}$ 存在した. ジョイントサポートのローリング 誤差（図 12 の $R_{i}$ 軸回りの姿勢誤差）がヨーイングと同等の約 $25 \mu \mathrm{rad} / \mathrm{K}$ とすると同様に $2 \mu \mathrm{m}$ 程度の測定誤差が 発生していることになる. 表 1 から変位 $\Delta u_{i}$ の計測許容值は $0.45 \mu \mathrm{m}$ である. そこで図の右側のように球面ジョイ ントまでのオフセットが最小となるようにロッドおよび電気マイクロメータの位置を変更した．これに伴い，ジ ヨイントサポートへ電気マイクロメータを接続するためのやや長いステーが必要となったが, 熱伸縮を抑えるた めにスーパーインバーで製作した．オフセットを $10 \mathrm{~mm}$ 以内にした際のアッベ誤差は $2 \mu \mathrm{m} / \mathrm{K}$ から $0.25 \mu \mathrm{m} / \mathrm{K} へ と$ 減少する. 


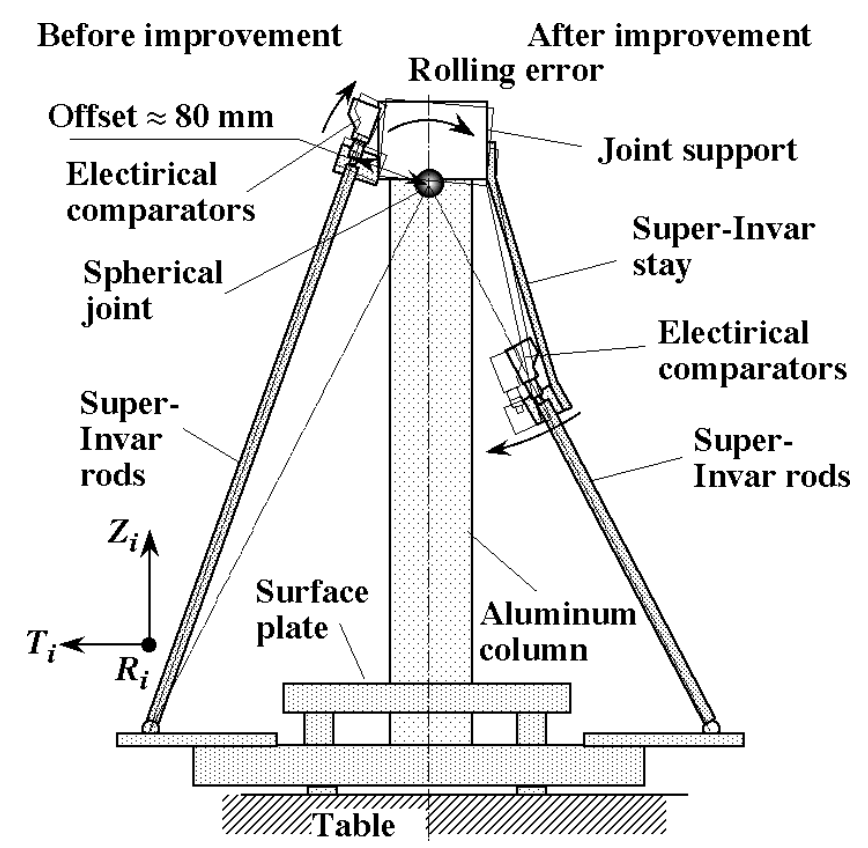

Fig. 12 Angular motion error of joint support in rolling direction

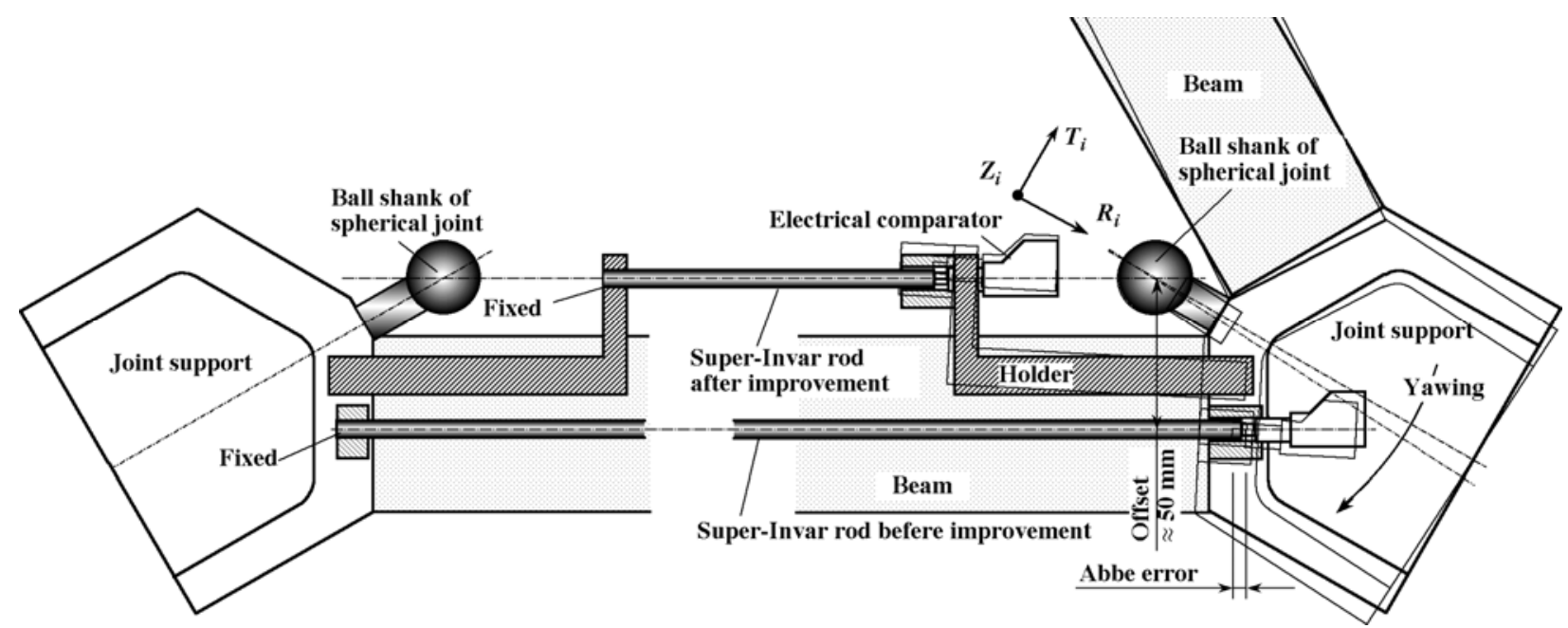

Fig. 11 Abbe error caused by angular motion error in yawing direction

\section{$3 \cdot 5$ ロッド支持方法の変更}

図 13 は 3.1 節から 3.4 節までに使われるスーパーインバー製ロッドと電気マイクロの取付け部分の詳細を示し ている．従来は図(a)のように，ロッドの案内はサポート（材質 : アルミ 63s）に加工した径 $\phi 7$ のリ穴により行 われていた。つまりロッドと穴はすべり接触をしていたため, ここで発生する摩擦力によって取付けステーの弾 性変形の発生や接触部のスティックスリップなどが発生し，正確な距離の変動が計測できない場合があったそそ こで図(b)に示すように，ロッドとホルダ間の案内を弾性支持とするために板ばね（t0.3 黄銅板）で連結し，摩擦 の影響を排除した。ロッドの他端は，図 8 右詳細図に示寸ように，上部ロッドでは固定支持，下部ロッドでは球 面軸受によって従来と同様に支持される.

図 14 は3.2節から述べてきた改良を施した補正システムを組み込んだパラレルメカニズム形三次元座標測定機 の外観を示す．図７と比較するとロッド位置が変更されていることがわかる. 


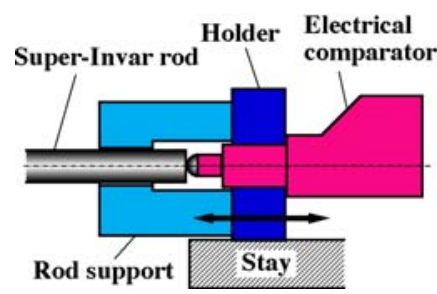

(a) Before improvement

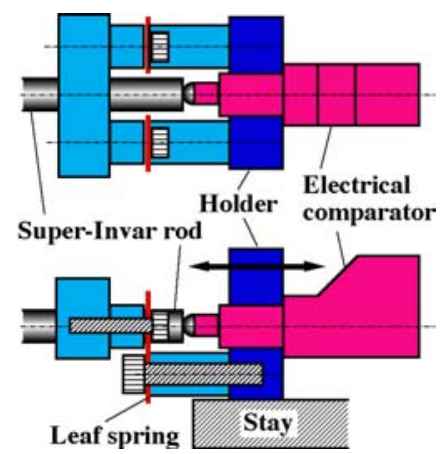

(b) After improvement

Fig. 13 Rod supporting methods

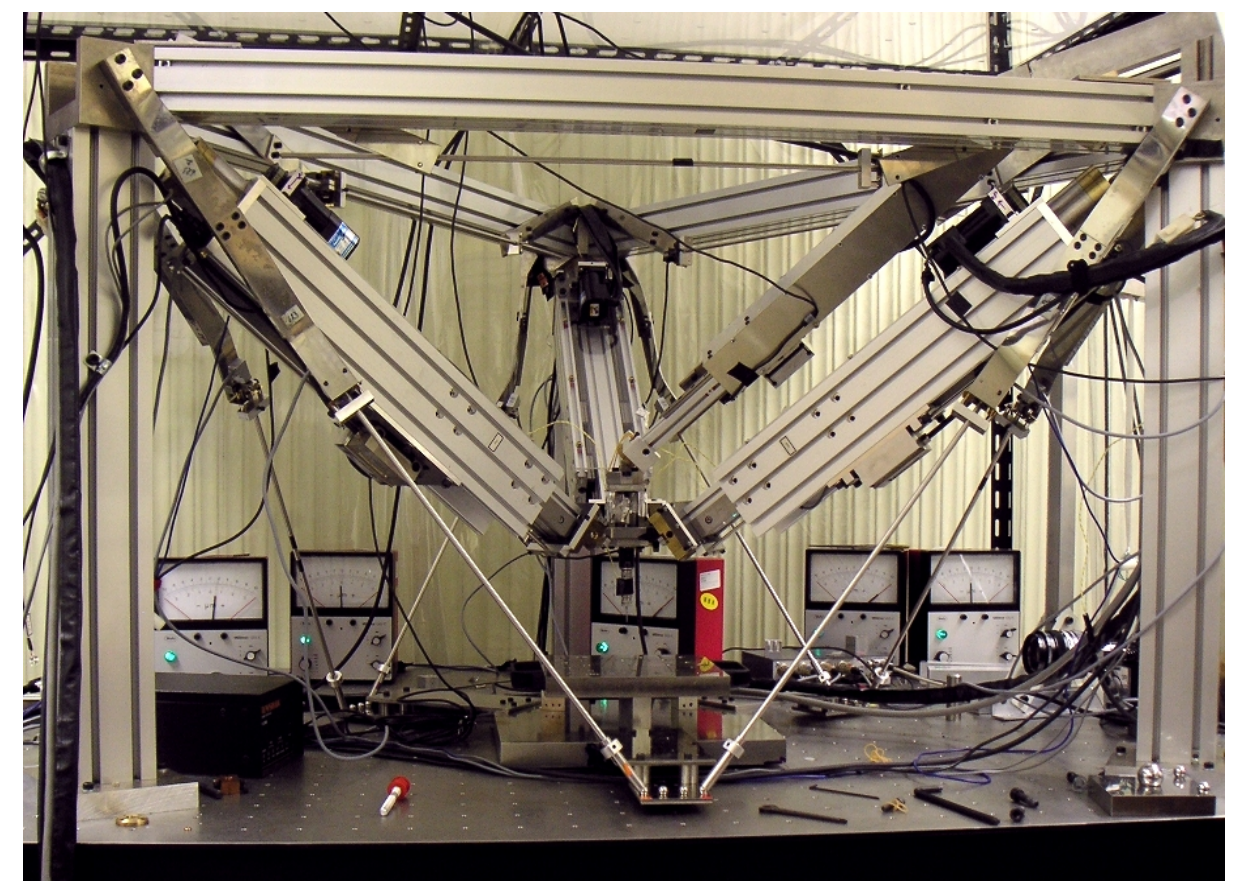

Fig. 14 Experimental coordinate measuring machine with improved compensation system

\section{4. 実 験}

フレーム変形の補正効果を調査するために，定点座標測定を行った．定盤上中央部に径 $1 / 2 "$ "基準球（SUJ2, グレード 20 , 公称真球度 $\leq 0.15 \mu \mathrm{m}$ ）を固定し， 3 自由度パラレルメカニズムのムービングステージに取り付けら れたタッチトリガープローブ (レニショーTP200, 単一方向繰返し精度 : $0.50 \mu \mathrm{m}_{2 \sigma}, X Y Z(3 \mathrm{D})$ 方向性誤差: $\left.\pm 1.40 \mu \mathrm{m}\right)$ により極点 1 点と赤道上 4 点を測定した. 5 点の座標值から最小自乗計算にて球中心座標を算出し, それを繰り 返した. フレーム変形があった場合は測定される球中心座標が変動するが, 本システムでそれを計測·補正ができ れば，測定值は一定の值となるはずである.

\section{$4 \cdot 1 \quad$ ロッド支持方法の変更結果}

図 15(a)は3.5 節で述べたロッド支持方法変更前における9台の電気マイクロメータの測定值の変動の一例を示 している．変更前には特に熱変位が小さい場合にロッド案内部の摩擦の影響が頻繁に観察された．そこで実験中 の温度勾配を小さくするためと空調機のオンオフに伴う温度脈動を排除するために, 空調機による室温制御は行 わずに自然な温度上昇のもとで実験を行った．図の横軸の測定回数は基準球表面 5 点の測定を 5 回として数えて いる. 温度上昇に伴い変位が増大しているが，ロッドとサポート穴間の静止摩擦によって特に $\Delta u_{4}$ と $\Delta u_{5}$ の変位の 


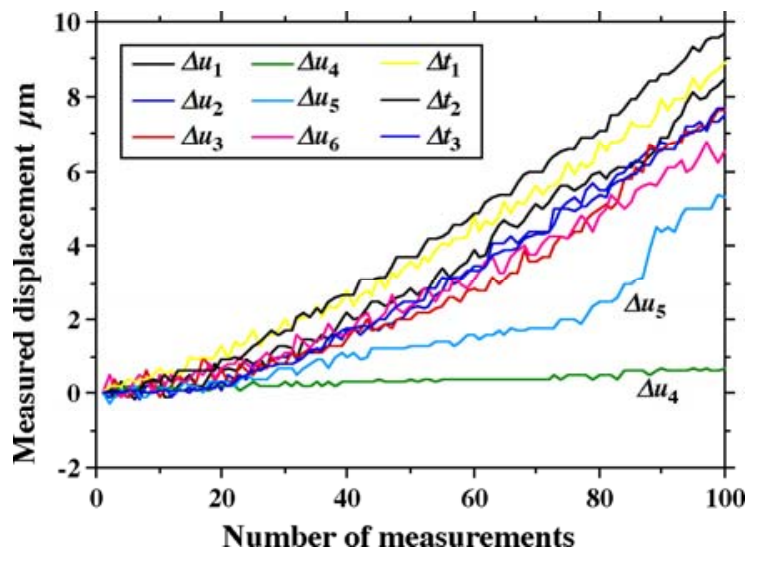

(a) Before improvement

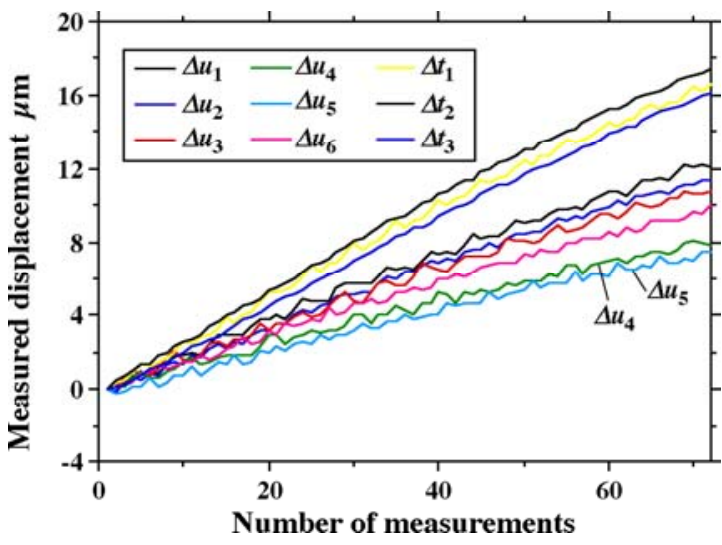

(b) After improvement

Fig. 15 Displacements measured by 9 electrical comparators and Super-invar rods

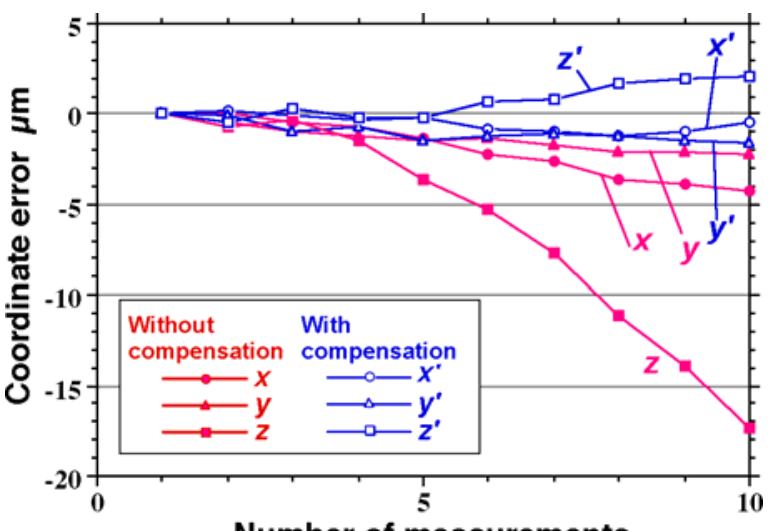

Number of measurements

(a) Before improvement ${ }^{(10)}$

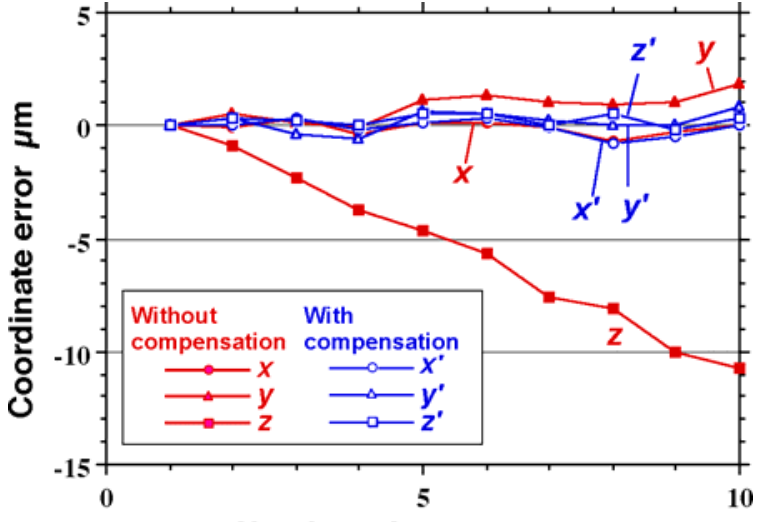

Number of measurements

(b) After improvement

Fig. 16 Variation of measured coordinates during measurement of master ball on surface plate before/after improvement

増加量が少なくなっている. 複数回の実験を行った結果, 常に $\Delta u_{4}$ と $\Delta u_{5}$ に図(a)のような停留が発生するわけでは なく, 他の変位計にも偶発的に発生したため, 3.5 節で述べたように摩擦の影響であると推察される. これに対し て, 図 13 で示した支持方法変更後の測定値の変化を図 $15(\mathrm{~b})$ に示寸. 図(a)のように変位の増加が停滞している箇 所がなく，摩擦の影響がなくなっていること推察される.

図15 (a)では室温上昇は $0.76^{\circ}$, フレームの部材温度変化は平均 $0.38^{\circ}$, 図 15 (b)ではそれぞれ $1.18^{\circ}, 0.88^{\circ}$ であった。

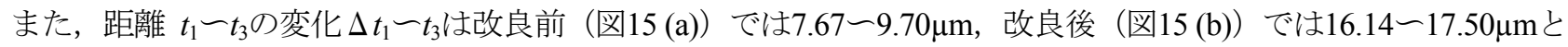
なった，それぞれを部材温度変化で除した值は，改良前では20.2 - $25.5 \mu \mathrm{m} / \mathrm{K}$ ，改良後では18.34 $19.89 \mu \mathrm{m} / \mathrm{K}$ とな

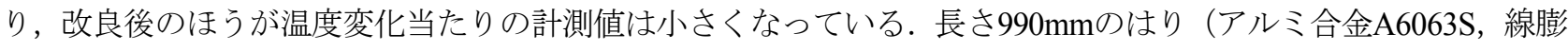
張係数 $23.4 \mathrm{ppm} / \mathrm{K})$ の $1{ }^{\circ} \mathrm{C}$ 当たりの熱膨張は $23.2 \mu \mathrm{m} / \mathrm{K}$ となり，これは改良前の測定結果 $(20.2-25.5 \mu \mathrm{m} / \mathrm{K})$ とほぼ

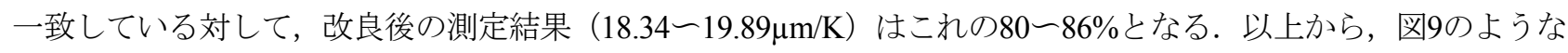
変形がフレームに生じているとすれば，改良後は基準点 $b_{1}$ 一b $b_{3}$ （球面ジョイント）間の距離の変動がより精度よ く計測されていると推察される.

\section{$4 \cdot 2$ 室温変動が大きい場合の補正結果}

次に補正システムの効果を検証するため温度勾配を比較的大きく設定し, 基準球の計測座標值の変動を調査し た．機械を設置している部屋の空調設備の設定温度を $5^{\circ} \mathrm{C}$ 上昇させ，フレームの平均温度を約 $1-2^{\circ} \mathrm{C}$ 程度上昇さ せた．補正装置改良前の球中心座標測定值の一例を図 $16(\mathrm{a}))^{(10)}$ に示す．横軸の測定回数は球中心座標の算出に必 要な 5 回の測定を 1 回として数えている. 温度上昇によりベースプラットフォームが上方へ移動するため, 測定 


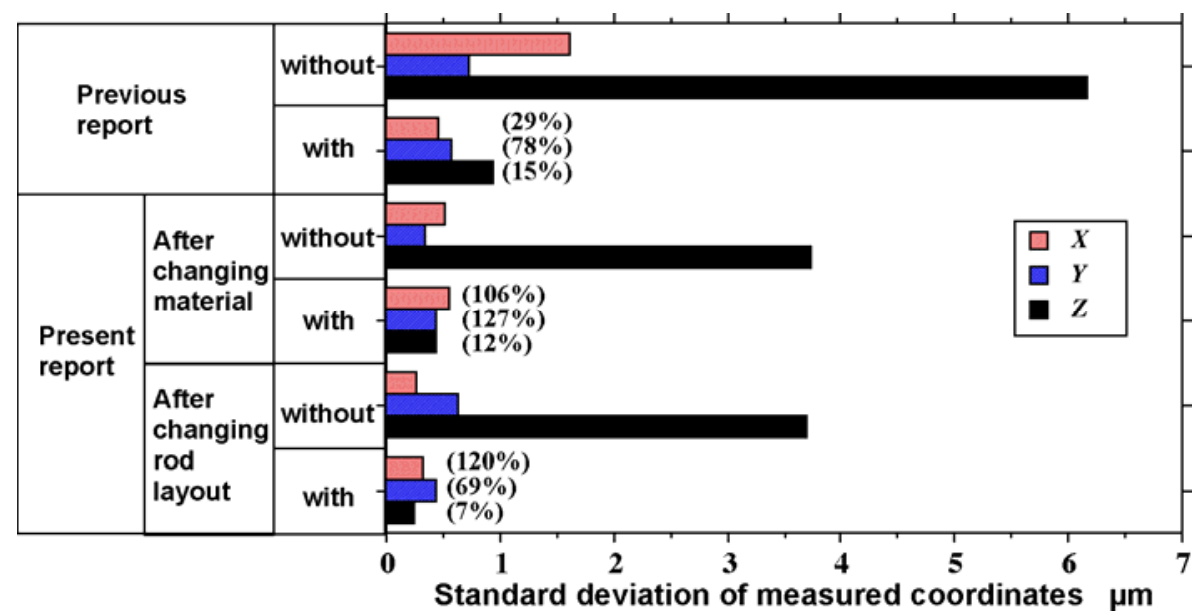

Fig. 17 Comparison of measured coordinates' precision with/without compensation, and before/after improvements

中に $Z$ 座標值は徐々に負方向へ推移し，10 回目の測定值では-17.3 $\mu \mathrm{m}$ に達している. フレームおよびメカニズム

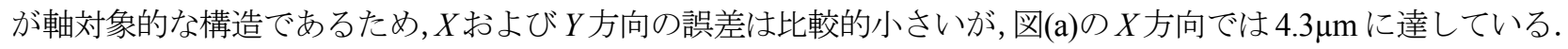
補正により $X, Y$ および $Z$ 方向の寸べてで座標值偏差が減少しているが， $Z$ 方向では約 $12 \%$ 程度の誤差 $(2.1 \mu \mathrm{m})$ が残っている. 本報でのロッド位置変更後の測定結果を図(b)に示す. 全体的に変更後のほうが補正精度が高いこ

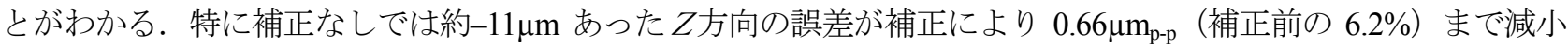
した.

図 16 では第 1 回目の測定座標值からの偏差を示したが, 各測定值にはフレーム変形の影響だけではなく,メカ ニズムの運動誤差やタッチプローブのプロービング誤差等も含まれるため, 第 1 回目の測定值も誤差を含んでお り，真の值ではない，そこで本補正システムを測定值の再現性（ばらつき誤差）で評価することとし，測定座標 值の標準偏差を計算した. 図 17 は材質の変更前後, およびロッドの配置を変更した後のフレーム変形補正有り, 無しの測定座標值を標準偏差で示した．補正ありの棒グラフの右側には補正無しの標準偏差を $100 \%$ とた值を 記した. この図から材質変更やロッド位置変更などの装置の改良に伴い, 補正無しと比べて補正後の標準偏差が 小さくなっていることがわかる. 特に $Z$ 方向については, 既報では補正を行っても誤差が $15 \%$ ぼ残留していた のが，材質改良後では $12 \% ，$ ロッド位置変更後では 7\%まで縮小した．前述のように $X Y$ 方向についてはフレー ムやメカニズムの軸対称性により既報でも誤差は小さかったが，本報の結果はさらにばらつきが小さくなってい る.

\section{$4 \cdot 3$ 外力作用時の補正結果}

本補正装置は同一の装置で温度変化による変形と外力・内力による弾性変型の補正が行えるという特長を有す る. 実際の機械の稼働時では熱膨張と弾性変形は同時に発生すると予想され, 最終的にはそれぞれの変形を足し 合わせたものになる．ここでは外力による影響のみを定量的に調査するため，室温を一定としフレームに外力を 加えてフレームを変形させた. 本機械は三次元座標測定機であるためプローブの測定圧（通常は $0.1 \mathrm{~N}$ 以下）以外 は外力が作用することはないが，実際にはマニピュレータの運動に伴う重心移動により， ベースプレットフォー ムの水平方向（ $X$ および $Y$ 方向）の移動が観察された（エンドエフェクタをワークスペース内で移動した際， $X$ および $Y$ 方向に最大で $\pm 0.5 \mu \mathrm{m}$ 程度)。これは図 1 に示寸ような三角柱形状を持つフレームにおいて，Z方向の荷 重はフレームの各柱に対する圧縮荷重となるために $Z$ 方向の剛性が高くなるのに対し, 水平方向荷重時では柱の 倒れが生じや寸く, 剛性が相対的に低くなるためである. 以上から水平方向から静荷重を加重し, 実験的に補正 効果を確認した.

まず定盤上に設置した基準球中心座標測定中の 6 回目以降において, 図 14 に示す機械フレームのはり中央部に $-X$ 方向（図の手前への水平方向）に $18.5 \mathrm{~N}$ の静荷重を加えた. 重心移動によるものより大きな変形に対する効果 を確認するため, 変形が約 $10 \mu \mathrm{m}$ となるように錘を選択した. 3.2 節で行われた材質の変更は力学的な変形補正効 果には効果がないと予想されるため, 図 18(a)は前報 ${ }^{(10)}$ の補正装置改良前, 図(b)は本報のロッド位置改良後の結 


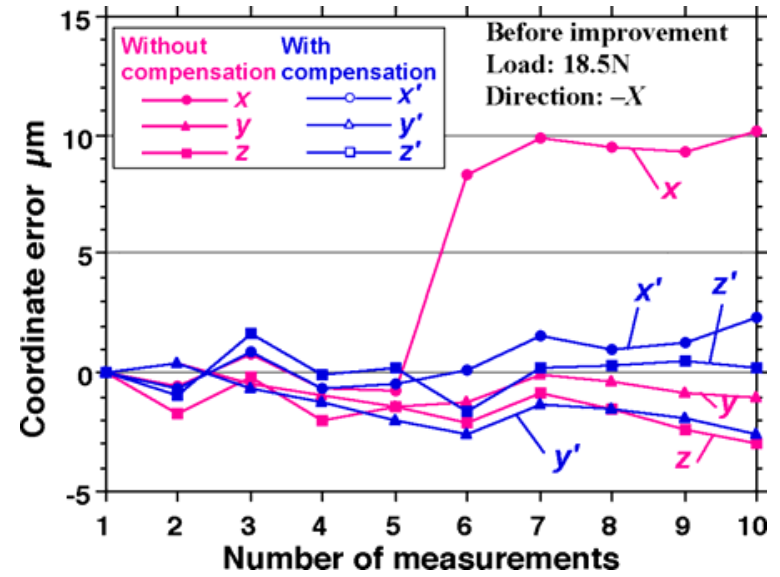

(a) Before improvement ${ }^{(10)}$

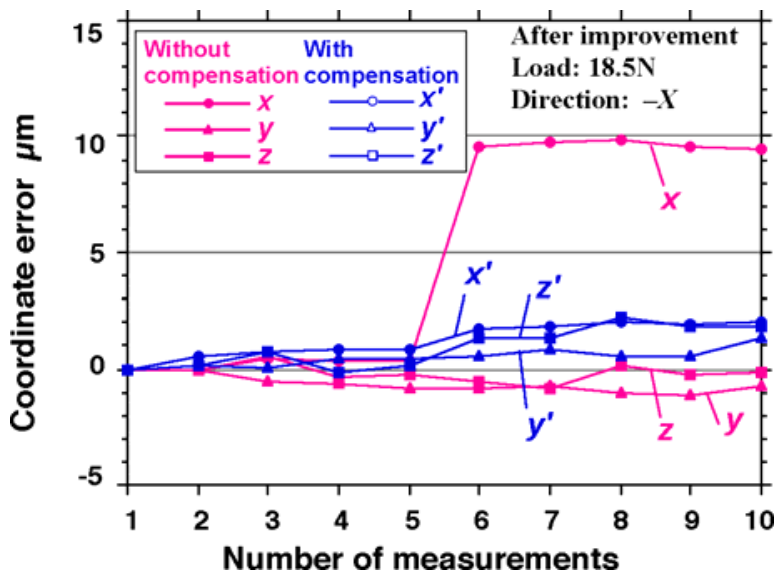

(b) After improvement

Fig. 18 Variation of measured coordinates under $18.5 \mathrm{~N}$ load in the $-X$ direction before/after improvement

果を比較して示す. 前報と本報の結果の両者において, 荷重によりベースプラットフォームが定盤に対して $X$ 方 向に変位し, 補正前の $X$ 座標值は約 $+10 \mu \mathrm{m}$ の偏差を生じている. 両者とも補正により $X$ 座標値は 2 - $3 \mu \mathrm{m}$ 以内と なっている（約 1/5 1/3）が，ロッド位置改良後の座標值（図(b)）のほうが全体的にばらつきが小さいことがわ かる. 補正後の座標值の標準偏差はロッド位置改良前は $X, Y$ および $Z$ 方向の偏差がそれぞれ $1.05 \mu \mathrm{m}, 1.02 \mu \mathrm{m}$,

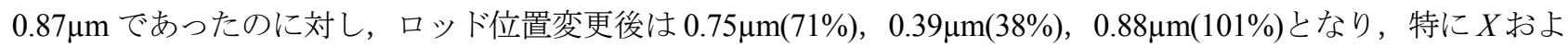
び $Y$ 方向でロッド位置変更の効果が現れている. これは上述のように特にフレームの水平方向の変形が大きいた めであると推察される。

\section{5. 考察}

3.5 節に述べたようにスーパーインバー製のロッドを弾性支持へ変更した結果，4 章図 15 で示したように計測 時の不具合 (停留) が無くなった. しかし, 板ばねに変位を発生させるための力が必要となり, 上述の取り付け ステー部を変形させ，ひいては計測精度の悪化を引き起こすことが懸念される. 図 15(b)では基準点間の距離の 変化は最大で $18 \mu \mathrm{m}$ が観察されており,この時に板ばね（ばね定数:約 $0.016 \mathrm{~N} / \mu \mathrm{m}$ ) には $0.016 \mathrm{~N} / \mu \mathrm{m} \times 18 \mu \mathrm{m}=0.29 \mathrm{~N}$ の力が発生し，これがステーに計測方向の弾性変形を生じさせている可能性がある．ステーの計測方向のばね定 数を計測したところ, 約 $0.4 \mathrm{~N} / \mu \mathrm{m}$ であり, 予測される $\boldsymbol{u}$ および $\boldsymbol{t}$ 方向の計測誤差は $0.29 \mathrm{~N} / 0.4 \mathrm{~N} / \mu \mathrm{m}=0.73 \mu \mathrm{m}$ と なる. 特に $\boldsymbol{u}$ 方向では表 1 の許容值 $0.45 \mu \mathrm{m}$ を越えており, $2.21 \times 0.73 \mu \mathrm{m}=1.61 \mu \mathrm{m}$ の補正誤差を発生していると推 察される. 以上のように, 温度変動・熱変位が大きい場合にはステーの曲げ変形は $1 \mu \mathrm{m}$ を越える補正誤差を発生 している可能性がある，上記の䛊差を減ずるためには，ステーの剛性を向上させる，あるいは板ばねのばね定数 を小さくすることが有効であると思われる.

\section{6. 結 言}

パラレルメカニズム形機械のメカニズムを支持するフレーム部の力学的および熱的変形による機械の運動精度 低下を防ぐために，定盤上の 6 個の基準点とベースプラットフォーム上の 3 個のジョイント間の 9 ケ所の距離の 変動を 9 台の変位計と低膨張材製のロッドを用いて計測・補正するシステムの改良を行った．既報ではロッド支 持部の摩擦に起因する変位計計測值の不具合が発生した。 また変位計のアッベ誤差や計測ループ内の機械要素の 熱変形などに起因し, 特に $Z$ 方向の補正精度が低下寸るという問題があった。このため本報では, まず各基準点 の位置誤差や変位計測誤差がベースプラットフォームの位置および姿勢測定精度へ及ぼす影響を定量的に調査す るため, 6 自由度へキサポッドの誤差解析を行った後, 以下の改良を行った.

(1) 9 組の変位計測軸がベースプラットフォーム上の 3 個の基準点を通るように, 変位計, ロッドおよびステ 一を配置し，アッベオフセットの低減を図った。 
（2）ロッド支持部の摩擦除去のために弾性案内（板ばね）を採用した.

(3) エンドエフェクタから被測定物までの計測ループの熱膨張を最小化するために，フレーム部材だけでは なくメカニズム内の部材の低膨張剤への置き換えを行った

以上の改良を行い, 定盤上に設置した基準球の繰り返し測定を行い, 以下のような補正効果の向上を確認した.

（1）ロッド支持部を板ばねで支持することにより摩擦が低減し，偶発的に生じていた測定值の停留がなくな った.

（2）機械温度を上昇させた場合の熱変形補正実験では，前報で $15 \%$ ぼ残っていた $Z$ 方向のばらつき誤差が 材質回前後では $12 \%$, ロッド位置変更後は 7\%まで減少した.

（3）フレームに水平方向に静的な外力を加えた場合は，XY方向の測定值のばらつきが改良前の 38 - $71 \%$ 程 度まで減少した。

本研究の一部は科研費基盤 $\mathrm{B}$, カシオ科学振興財団, 中部電力基礎技術研究所およびマザック財団の各助成金 により行われた．以上記して謝意を表する.

\section{文献}

(1) Mamesh R., Mannan M. A., and Poo A. N., "Error compensation in machine tools - a review Part II: thermal errors", International Journal of Machine Tool Manufacture, Vol. 40, No. 9 (2000) pp. 1257-1284.

(2) Krlewich, D. A., "Temperature integration model and measurement point selection for thermally induced machine tool errors", Mechatronics, Vol. 8, No. 4 (1998), pp. 395-412.

(3) 大矢 誠, “三次元座標測定機の精度に及ぼす温度環境の影響（室温の異なる環境における誤差分布の变化とその 補正）”, 日本機械学会論文集 C 編，Vol. 63，No. 631（1999），pp. 1247-1254.

(4) Vanherck P., Dehaes J., and Nuttin M., "Compensation of thermal deformations in machine tools with neural nets", Computers in Industry, Vol. 33, No. 1 (1997), pp. 119-125.

(5) Attia M. H., and Fraser S., "A generalized modeling methodology for optimized realtime compensation of thermal deformation of machine tools and CMM structures", International Journal of Machine Tools and Manufacture, Vol 39, No. 6 (1999), pp. 1001-1016.

(6) Oiwa T., "New Coordinate Measuring Machine Featuring a Parallel Mechanism", International Journal of the Japan Society for Precision. Engineering., Vol. 31, No. 3 (1997), pp. 232-233.

(7) Zhuang H., "Self-Calibration of Parallel Mechanisms with a Case Study on Stewart Platforms", IEEE Transactions on Robotics and Automation, Vol. 13, No. 3 (1997), pp. 387-397.

(8) Patel A. J. and Ehmann K. F., "Calibration of a hexapod machine tool using a redundant leg", International Journal of Machine Tools and Manufacture, Vol. 40, No. 4 (2000), pp. 489-512.

（9）大岩孝彰，京極正人，山口浩希，“パラレルメカニズムを用いた三次元座標測定機（第 5 報）-立体的なボールプ レートを用いたキャリブレーション-”，精密工学会誌，Vol. 68，No. 1 (2002)，pp.65-69.

(10) Oiwa T., "Error Compensation System for Joints, Links and Machine Frame of Parallel Kinematic Machine", International Journal of Robotics Research, Vol. 24, No. 12 (2005), pp. 1087-1102.

(11) 大岩孝彰，玉木雅人，“6自由度パラレルメカニズムにおけるアッベの原理に関する研究（対偶の回転誤差が機 構の運動誤差に及ぼす影響)”，日本機械学会論文集C編，Vol. 69，No.678（2003），pp.472-477.

(12) Smith S. T., and Chetwynd D. G., "Foundations of Ulatraprecision Mechanism Desing", Gordon and Breach, London (1992), p.66. 